\title{
Role of organizations in preparedness and emergency response to flood disaster in Bangladesh
}

\author{
Babul Hossain
}

\begin{abstract}
The present study is to know the role of organizations and make an assessment on their assistance regarding preparedness and emergency response of flood disaster affected people. This study has used a mixed-method approach. Flood-affected people were the respondents to evaluate the organizational role. The study reveals that before the flood in 2017 to minimize the loss and damages, the GOs play a very effective role concerning the arrangement of preparatory meetings and preparing shelter centers, and NGOs play a very useful role in making arrangements for awareness-building training. During the emergency period, the GOs played a comparatively better role in providing $\mathrm{Cl}$ sheets, agricultural assistance and cash money as relief for establishing housing facilities and emergency support. The NGOs played relatively a better role in providing food, water, clothes, medicine, etc. This study put forward complications such as limited sanctions, disruption of communication, lack of awareness of sufferers, and overlapping. The findings of this study would be a significant for the disaster policymakers, and civil societies.
\end{abstract}

Keywords: Organizations (GOs \& NGOs), Flood disaster, Preparedness, Emergency response, Bangladesh

\section{Introduction}

Bangladesh is one of the highly flood disaster-prone countries in the world. Every year thousands of people are being affected by the flood; and they become hopeless by losing their family members, relatives, and entire properties. Therefore, immediately after such incidents, organizational supports are very much needed to them. Almost $80 \%$ of the country consists of the flood plain of the GBM basins, and some other minor rivers (Brouwer et al. 2007). Among the flood-prone areas of Bangladesh, Char land (Island) is the most susceptible to frequent flood, and the dwellers of these places are the supreme vulnerable. There is an estimation that approximately 4$5 \%$ of the population in Bangladesh lives in the char's land which covers almost $7200 \mathrm{~km}^{2}$ (Kelly and Chowdhury 2002; Mondal et al. 2015; Paul and Islam 2015). At

Correspondence: hossainbabul@hhu.edu.cn

Department of Sociology, School of Public Administration, Hohai University, No.8 Focheng West Road, Jiangning, Nanjing 210000, China least 58 major floods hit in Bangladesh from 1954 to 2017, and 20,039 people died and also millions of people affected owing to catastrophic flood throughout the last 47 years (1970-2017) (Relief 2013). In which 1966, 1987, 1988, 1998 and 2007 flood was the most devastating flood which affected millions of people in Bangladesh. Likewise, this country faced one of the worst river flooding events on 12 August 2017, with high water levels record, and the Ministry of Disaster Management and Relief (MoDMR) stated that the floods were the most awful in at least 40 years (Philip et al. 2019). It disrupted people's normal life immensely. Thirty-one (31) districts affected ruthlessly among the 64 districts of Bangladesh (Management 2007), and around 6.9 million people were affected (Philip et al. 2019), with 121 people dead (Nirapad 2017). Apart from these, crop damaged, disruption of communication and education, health issues, food problems, drinking water crises, and massive displacement were the main causes to make them more
Springer Open (c) The Author(s). 2020 Open Access This article is licensed under a Creative Commons Attribution 4.0 International License, which permits use, sharing, adaptation, distribution and reproduction in any medium or format, as long as you give appropriate credit to the original author(s) and the source, provide a link to the Creative Commons licence, and indicate if changes were made. The images or other third party material in this article are included in the article's Creative Commons licence, unless indicated otherwise in a credit line to the material. If material is not included in the article's Creative Commons licence and your intended use is not permitted by statutory regulation or exceeds the permitted use, you will need to obtain permission directly from the copyright holder. To view a copy of this licence, visit http://creativecommons.org/licenses/by/4.0/. 
vulnerable in the flood-prone areas. Thus, flood disaster is such an event that cannot be prevented from happening, but the impacts can be reduced if effective measures are taken in time to reduce their severity, frequency, and possible size.

In Bangladesh, response to flood disaster at the national level, the Ministry of Disaster Management and Relief (MoDMR), and the Department of Disaster Management coordinate overall disaster management efforts. At every district, sub-district, and union level, there are disaster management committees. In 1997, the Ministry of Food and Disaster Management (MoFDM) issued a Standing Order on Disaster $(\mathrm{SOD})^{1}$ which, in detail, describes the duties and responsibilities of all the concerned government agencies for disaster management (Hasan et al. 2013). On the other hand, NGOs operate at the grass-root level with communities and local organizations as partners and take a participatory approach to development planning. It is known that NGOs enjoy higher operational flexibility as they are relatively free from bureau structures and red-tapes; and they are able to respond and adapt quickly and easily and often work on behalf of the neediest, the poorest and the most vulnerable group (ISDR 2006). There are several NGOs working in the study villages such as SKS, GUK, SHACO, BRAC, ASA, etc. (Portal 2018). And, there was no exception of organizational activities as regards flood in 2017. Immediately they come forward to help the flood-affected people and extended their helping hand in different phases by taking numerous measures.

Therefore, it is apparent that although Govt. and Non-govt. Organizations took various initiatives to support to the flood disaster-affected people; these supports are not sufficient to cover the entire disaster-prone area or to cover entire disaster-affected people. Moreover, is their role fully effective in regaining the affected people's normal course of activities and sustainability in the livelihood? Therefore, the present study is to evaluate the role of organizations regarding preparedness and emergency response and also try to find out the loopholes and drawbacks of organizations' responses to the 2017 flood-affected people in terms of people perception.

\section{Flood research scenarios: a brief review}

In the context of flood disasters researches, most of the researches have been focused on the concept of vulnerability (Burton et al. 1993; Cannon 1994; Cannon et al.

\footnotetext{
${ }^{1}$ Standing Orders on Disaster was issued by the National Disaster Management Council (NDMC) under the direction of the Government of the People's Republic of Bangladesh.
}

2003; Few 2003; Ibrahim et al. 2017; Nur and Shrestha 2017; Smit and Pilifosova 2003). In the same way, few studies have emphasized the characteristics of the flood, the geographical location, the geomorphological setting and the cultural, political and socio-economic conditions of the people at risk of flooding (Alcántara-Ayala 2002; Choudhury 2005; Few 2003; Mutton and Haque 2004; Thompson and Penning-Rowsell 1994; Zaman 1989, 1993). Also, several studies focusing on the effects of floods and population displacement (Del Ninno et al. 2003; Dun 2011; Gray and Mueller 2012; Islam et al. 2010; Paul and Rasid 1993; Zaman 1996) and the impact of climate change on the upcoming flooding (Kafi 2010; Mirza 2002). There are some studies on the evaluation of existing structural flood dam projects (Hoque and Siddique 1995; Hossain and Sakai 2008), Flood mitigation activities and their effectiveness (Shajahanl 2001) and evaluation flood management strategies, including institutional measures (Adnan 1991; Brammer 1990). Besides, there are many researchers conducted on the context of people's indigenous/local knowledge and coping strategies to response flooding (Hossain et al. 2019; Howell 2003; Islam et al. 2018; Paul and Hossain 2013; Paul and Routray 2010). Thus, most of the research accessible on the literature that uncovers the existing literature is based on socioeconomic perspectives to determine the impact and magnitude of floods and adjust strategies. On the other hand, some articles found as regards to people's perception about flood management and mitigation dealings take on by GOs and NGOs (S. K. Paul and Hossain 2013) and also the role of NGOs to response of flood disaster management (Matin and Taher 2001). After reviewing several pieces of literature, it can be said that although many research works have been done in the field of flood disaster management but a few researches have been done on the organizational role in preparedness and emergency response to flood disaster-affected people. Therefore, there is a clear research gap here. Regarding this, to fill this research gap the study purpose to analyze the preparedness and emergency response to flood disaster carry out by the GOs and NGOs and also evaluate people's perceptions and satisfaction on their performances.

\section{Disaster management settings in Bangladesh: GO- NGO collaboration}

The relationship between the GO and the NGO is a talking point in Bangladesh. After the devastating cyclone of 1970 and the liberation war in 1971, the social structure was changed, and the economy was destroyed. Several non-government organizations were set up in that time to undertake the massive task of rehabilitating the war-ravaged country. In independent Bangladesh, NGOs have emerged and grown very fast. 
It is often said that Bangladesh is a very fertile land for NGOs. Since the beginning of the 1970s, Bangladesh has virtually become a laboratory for the design and experimentation of different rural development models and approaches. Various agencies of Government of Bangladesh, international donors, and the non-government organizations have experimented with different models and approaches of institutionbuilding for rural and local level development (Aminuzzaman 2000). These organizations were also actively involved in providing their efforts with emergency response, recovery and rehabilitation activities to manage disasters over the periods.

Among international organizations CARE, Islamic Development Bank (IDB), United Nations, UNICEF, WFP, and among non-governmental organizations World Vision, Oxfam Australia. Muslim Aid, ASA, Proshika, BRAC, SKS, GUK were especially involved with relief and rehabilitation activities. Besides, Grameen Bank, Proshika, BRAC and ASA, etc. also operate microcredit program that acts as a social safety net during a disaster (Hossain 2012). Comprehensive Disaster Management Program, with the technical assistance of UNDP, is presently in operation for the integration of disaster and development concept as well as for improvement in coordination between GO -NGOs' efforts in response to disasters at all levels.

A review of the collaboration indicates three major types of arrangements: (a) Subcontract; (b) Joint implementation; and (c) Government as a financier of NGO projects (Bank 1996). The most common collaboration is the sub-contracting arrangement where Government agencies enter into contracts with NGOs. Joint implementation on a partnership arrangement, where NGOs are involved either as co-financier or joint executing agency with the Government, is least practiced. In the area of micro-credit, there is an emerging trend for the Government to finance NGOs' credit operations.

The government, NGOs, people, and friends around the world worked together in minimizing the impact of the calamity through preparedness as mitigation measures as well as coping with the aftermath. The government and non-government organizations worked in a coordinated manner to bring relief to suffering people (Blair 2005). The task was too great, and the scope remained for improving the situation. Based on different studies and documents, it was found that the role of NGOs in disaster management in Bangladesh is significant. Presently, NGOs are giving emphasis to work on preventive measures as a strategy of disaster risk reduction as numerous private donors and different parts of CARE's international organization.

\section{Materials and methods}

\section{Study area}

Bangladesh has many flood-prone areas in which Rangpur division is one of the most vulnerable areas. Regarding this, Rangpur division has been selected purposively; and multistage area sampling method has been applied for selecting subsequent administrative units as well as the ultimate sampling unit, which is the village. Subsequent administrative units were selected purposively according to the severity of flood in terms of people affected, death toll, losses, and damages. Among the Rangpur division, Gaibandha district is very adjacent to the river basin, and it is the most susceptible district to happen frequent flood. From the Gaibandha district, two Upazila (Sub-district) have been selected. The study area selection procedure is as follows (Fig. 1):

The study areas are riverine islands (Char) in Brahmaputra Rivers and geographically isolated from the mainland (see the Fig. 2). The socio-economic condition of the study area is very fragile. There are some poor indicators of the income of these households such as share-cropping, agricultural day labor, and livestock rearing, small business, fishing, boatman etc. However, the flood and riverbank erosion are continuing the process to destroy their crops, crops lands, homesteads. The dwellers of char, about $80 \%$ are living under ultra-poor (Islam 2018).

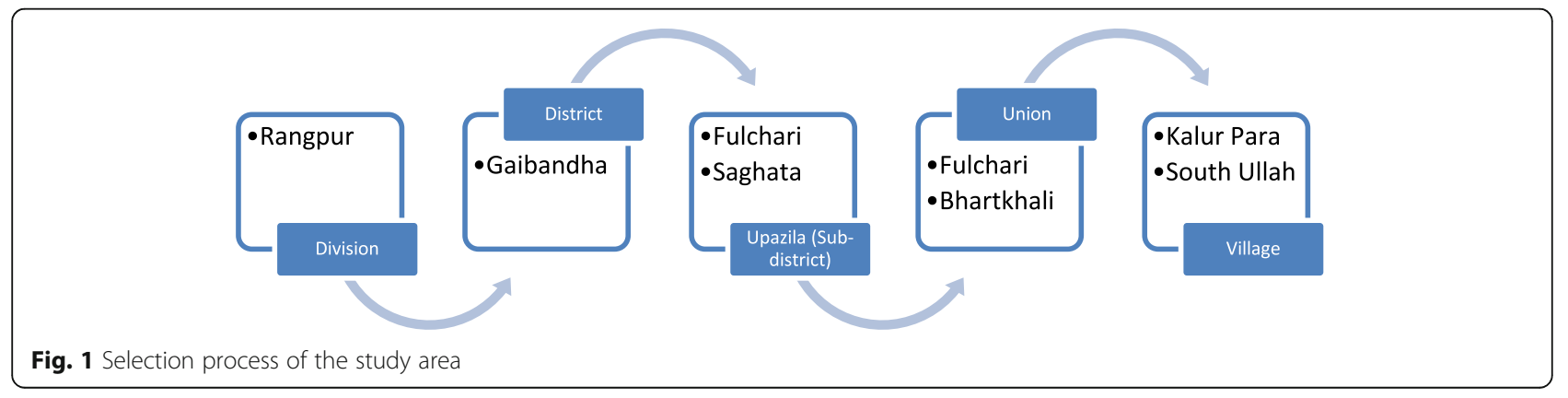




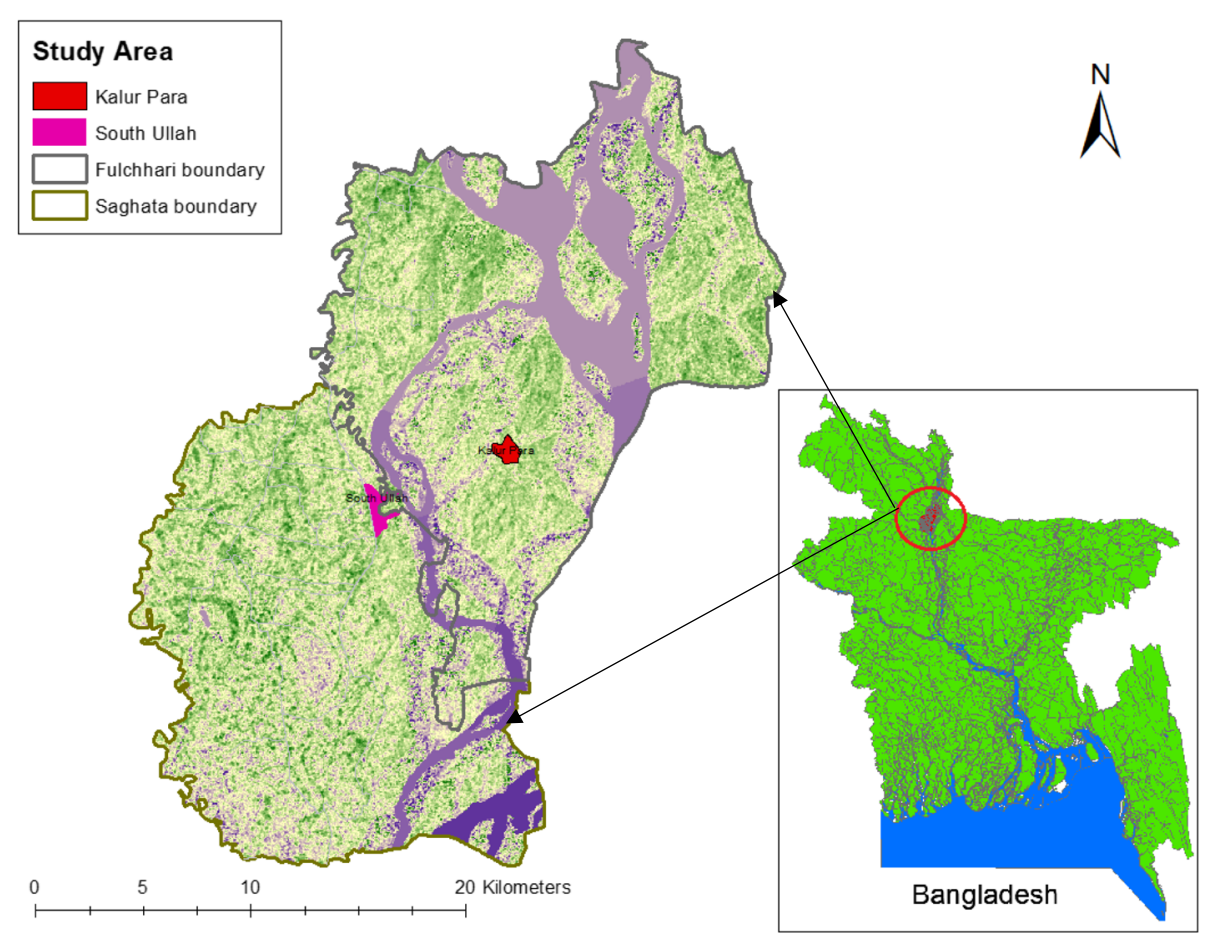

Fig. 2 Map of the study area location (Using Arc GIS 10.5)

\section{Data collection, analysis and interpretation}

This study has used a mixed-method approach. Data for the study have been collected from both the primary and secondary sources. Along with the secondary literature review, questionnaire survey, observation, focus group discussion (FGDs) and key informant interviews (KII) have been conducted from the two study villages that were the most ruthlessly affected by the catastrophe flood in 2017. Floodaffected people were the respondents to evaluate organizational role. The researcher prepared two sets of structured interview schedule with close and open-ended questions to collect data based on the objectives of the study. At first, respondents have been selected among the flood-affected households (total households 1843) of two selected villages by using simple random sampling. According to the prevalent culture of Bangladesh, almost all households are centered by the male heads of households. Therefore, respondents were the heads of the households.

For determining a representative sample size from the category, the researcher has used the following statistical formula-(Kothari 2004)

$$
n=\frac{z^{2} \times p \times q \times N}{e^{2}(N-1)+z^{2} \times p \times q}=319
$$

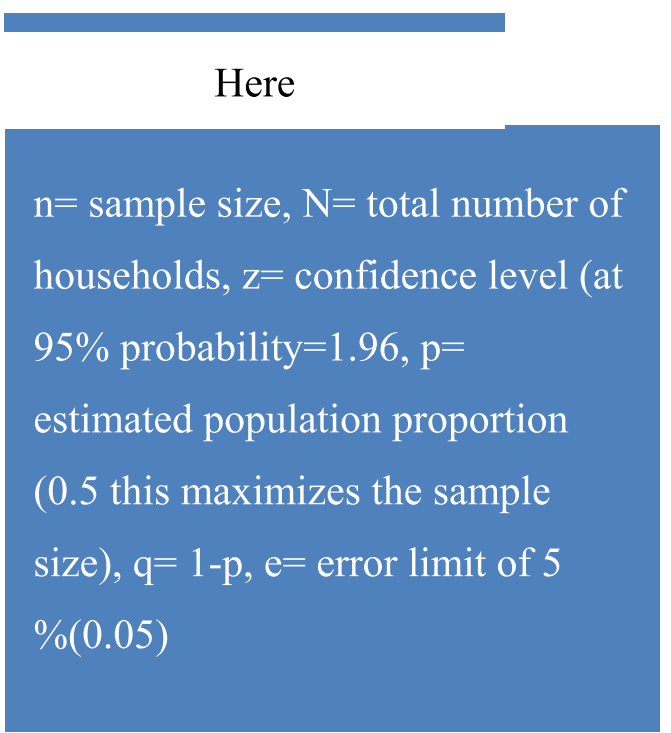

Focus group discussion participants were recruited from the household questionnaire survey. Respondents to the survey who had been flooded were asked if they would be willing to participate in a focus group discussion to explore some of the issues in greater depth. Each of the FGDs group had 6-12 number of people participated alongside two or three members of the project team. Interviews and focus groups discussion were held in the Bengali language, and each session was recorded onto audiotape. 
After completing the interview sessions, collected data have been analyzed according to the objectives of the study. Quantitative data have been analyzed by using statistical tools, i.e. Statistical Package for Social Sciences (SPSS) software version 20 and Microsoft Excel. Qualitative data have been interpreted through textual and document analyses. Five-point Likert scale has been used to analyze data on the attitude, experiences, and satisfaction of the disaster-affected people (Likert 1932).

\section{Results and discussion}

An organization can play a vital role in overcoming its limitations in an organized way when disaster-affected people feel essential help before disaster and during the emergency period. There are two types of organizations in the country (GOs and NGOs) which play their role for the betterment of the affected people in the crucial moment. In Bangladesh, sustainable development is closely linked with disaster reduction which needs an effective disaster management plan. Within the disaster management plan, preparedness and emergency measures are taken by the government and the nongovernment organizations to minimize the loss and damages caused by natural disasters like floods and also for its restoration. With government organizations, NGOs take part in flood reduction activities, rescue, and recovery operations. Besides this, food and non-food support are also being provided at the time of the flood disaster. Though we cannot protect flood disasters, some early initiatives and preparation can lessen the amount of loss and damages. It can help in saving lives and properties caused by flood disasters; and if a flood occurs, the emergency response should be taken for the severely affected people when they become helpless and hopeless. This study has also designed to portray the role of various organizations during preparedness and emergency situation.

\section{Role of organizations in preparedness}

Disaster preparedness performed to ensure adequate response to its effects as a measure of action taken before the disaster occurred, and relief and recovery from its consequences eliminated the need for any last-minute activity. Various agencies and individuals conduct flood disaster preparedness activities. Everyone has a distinctive role to play and unique accountabilities to achieve when the flood disaster walkout. The aims of flood disaster preparedness are - realizing what to do next in a disaster, knowing how to do it and equipping the right tools to do it successfully. This challenging procedure might be able to take years before achieving a suitable levels and retaining such levels is a continuing determination (Coppola 2006). This section shows the present condition of preparedness system in the study area by following heads and subheads.

\section{Preparedness regarding receipt of information}

Along with Government Organization, the Nongovernment Organization plays very effective role to manage the flood disaster before happening the flood. In which information is an essential tool of the preparedness system in the flood disaster management perspective in Bangladesh arena. Because of providing real information in time, vulnerable and affected people can save their lives and properties. There is a huge member of staff working in GOs and NGOs concerning disasterrelated activities in the diverse territory in Bangladesh. They undertake different kinds of measures to collect disaster related information from numerous sources. Then, if there is a possibility to happen a disaster like a flood, service providers actively work to disseminate the disaster' information accurately to the vulnerable areas. Actually, organizations spread several types of information before happening the flood disaster like what will be the intensity of the upcoming flood, what types of measures should be taken, where should take shelter, and so on. Dissemination of information regarding flood disaster, the medium of information and time span of receiving information has been analyzed as follows.

Table 1 shows that $93.7 \%$ of respondents received information before the devastating flood in 2017 occurred in the study area, and only $6.3 \%$ of respondents did not obtain any information about the flood. Table data also shows that the information receiving rate is almost the same $(91.7 \%$ and $95.7 \%)$ among the two study villages. So, it can be said that the government and nongovernment organizations were very much prompt to provide information. It is also mentionable that the respondents who did not receive information before the disaster; some of them were out of the study area.

Table 1 also shows that $16.1 \%$ of respondents received information by radio, and only $8.7 \%$ of respondents received information by TV at first. The highest number of respondents (52.2\%) received information from the announcement of Union Disaster Management Committee (UDMC) by announcing through loudspeakers, $15.7 \%$ of respondents were informed about the flood disaster from their neighbor, and only $7.4 \%$ of respondents received flood-related information from other sources. It is significant that announcing through loudspeakers is much popular and important way to provide flood disaster-related information to the people of the floodprone area as most of the rural people have no electronic device to collect information and they remain engaged with their daily activities in the agriculture and other fields. One of the Key Informant Interviewees has also expressed the same opinion, but he added that the 
Table 1 Dissemination, source and time span of receiving of information

\begin{tabular}{|c|c|c|c|c|c|c|}
\hline \multirow[t]{2}{*}{ Name of study villages } & \multicolumn{4}{|c|}{ Getting information before flood } & \multirow[t]{2}{*}{ Total } & \multirow[t]{2}{*}{ Percentage } \\
\hline & Yes & $\%$ & No & $\%$ & & \\
\hline Kalur Para & 143 & 91.7 & 13 & 8.3 & 156 & 100 \\
\hline South Ullah & 156 & 95.7 & 7 & 4.3 & 163 & 100 \\
\hline Total & 299 & 93.7 & 20 & 6.3 & 319 & 100 \\
\hline \multicolumn{7}{|l|}{ Source of information } \\
\hline Category & \multicolumn{4}{|l|}{ Frequency } & & Percentage \\
\hline Radio & \multicolumn{4}{|l|}{48} & & 16.1 \\
\hline Television (TV) & \multicolumn{4}{|l|}{26} & & 8.7 \\
\hline Miking by GOs \& NGOs & \multicolumn{4}{|l|}{156} & & 52.2 \\
\hline Neighbor & \multicolumn{4}{|l|}{47} & & 15.7 \\
\hline Others & \multicolumn{4}{|l|}{22} & & 7.3 \\
\hline \multicolumn{7}{|l|}{ Receiving time } \\
\hline \multirow[t]{3}{*}{ Name of study villages } & \multicolumn{4}{|l|}{ Time } & Total & Percentage \\
\hline & \multicolumn{2}{|l|}{ In Time } & \multicolumn{2}{|l|}{ Late } & & \\
\hline & Frequency & $\%$ & Frequency & $\%$ & & \\
\hline Kalur Para & 114 & 79.7 & 29 & 20.3 & 143 & 100 \\
\hline South Ullah & 141 & 90.4 & 15 & 9.6 & 156 & 100 \\
\hline Total & 255 & 85.3 & 44 & 14.7 & 299 & 100 \\
\hline
\end{tabular}

Source: Field Survey June-September, 2018, December 2018-April, 2019

local mosque (a Muslim place of pray) could be the announcement center as part of preparedness just before the disaster.

By receiving real information in time, vulnerable affected people can save their lives and properties. Table 1 shows that $85.3 \%$ of respondents (out of information receiver) received information in time, and as a result, they could take preparation to save their valuable assets and their family members. Rest $14.7 \%$ of respondents received information lately. Concerning this, the respondents claimed, they could not get information in time due to lack of electronic compliance such as radio, television, as well as some of them reported, they were out of the home while providing information by organization. For this reason, they could not take measures timely. Table 1 also shows that the highest number of respondents (90.4\% out of 156) from South Ullah received information in time and $(79.7 \%$ out of 143) of respondents were from Kalur Para. Findings show that most of the respondents (85.3\%) from the study areas received information in time and it also indicates the promptness of government and non-government organizations, but because of the severity of the flood, the affected people lost almost everything.

\section{Readiness concerning shelter Centre}

Shelter center is essential for the vulnerable people of the disaster-prone area to save the people and their valuable goods and documents during any devastating natural disaster like flood, cyclone, etc. though the number of shelter center is not enough for the affected people in the study area. There are only a few shelter centers in Rangpur division, which are not enough considering the vast population (Statistics 2016). Generally, the Government makes education institutions as a shelter center in the disaster-prone areas due to lack of available shelter centers. On the other hand, Non-government organizations make temporary basis shelter centers in a high place and local NGOs' offices. Therefore, Organizations tried to create awareness among the people about the severity of flood disaster and tried to motivate for taking shelter in the shelter center.

Table 2 shows that $60.5 \%$ of respondents took shelter during the last 2017 flood disaster where $39.5 \%$ of respondents did not go to the shelter center for taking shelter. Table 2 also shows that the highest number of the respondents (60.8\%) from Kalur Para went to the shelter center.

Table 2 Distribution of the respondents by going to the Shelter Centre or not

\begin{tabular}{lllllll}
\hline Taking Shelter & Kalur Para & \% & South Ullah & \% & Total & $\%$ \\
\hline Yes & 87 & 60.8 & 94 & 60.3 & 181 & 60.5 \\
No & 56 & 39.2 & 62 & 39.7 & 118 & 39.5 \\
Total & 143 & 100 & 156 & 100 & 299 & 100 \\
\hline
\end{tabular}

Source: Field Survey June-September, 2018, December, 2018-April, 2019 
Among the respondents who (39.5\% out of 118$)$ did not go to the shelter center out of them, $34.7 \%$ did not go for long-distance. There were some other reasons for not going to the shelter center such as; $9.3 \%$ for weak shelter center, $13.6 \%$ for negative attitude, $22.9 \%$ for lack of information and 19.5\% for taking initiatives lately (see the Fig. 3). Field observation showed that approximately $4 \mathrm{~km}$ distance from the mainland to char village, but most of the permanent shelter is more far away from the study area. Usually, most of the people do not take shelter due to their homesickness; they always wait until the floodwater hit their household. Local people always say, "We are dying or alive, we won't go elsewhere from our father, and Grandfather Homestead, rather than we will die here". Therefore, according to the people's perception, it can be said that more shelter centers need to be built to minimize long-distance.

For better preparedness, preparatory meeting, training program, preparing shelter center and medical preparation are very much essential to save the people and properties from the uncertain flood disaster. The following table shows the people's perceptions regarding effective initiatives taken by the organizations.

The preparatory meeting is very much important to know the real scenario of the general people of the disaster-prone area. Several types of government and non-government organizations arrange the preparatory meeting from time to time. The Table 3 shows that the most of the respondents (53.0\%) think that the government organization can arrange the preparatory meeting successfully under Union Disaster Management Committee (UDMC) where NGOs have also representatives but $33.9 \%$ of respondents think that NGOs can arrange meeting successfully and rest $13.1 \%$ of respondents think both of the organizations can arrange the meeting successfully. The respondents define here success on the basis of the presence of committee members and the implementation of the decision taken in the meeting.

Training Program creates awareness among the floodprone area's people to protect themselves and their valuable goods when flood disaster hit. Generally, organizations arrange the training program including general people of the study area who are under the risk of flood disasters.

According to the Table $321.6 \%$ of respondents think that government organizations arrange the training Program effectively, and the highest number of respondents (54.9\%) believe that non-government organizations can arrange the training program effectively and the rest $23.5 \%$ of respondents feel that both of the organization can arrange the training Program effectively including the local vulnerable people. It is significant that most of the respondents show their positive attitude towards non-government organizations regarding arranging training Program effectively.

Before any flood disaster, shelter center should remain prepared for the poor disaster-affected people whose own shelter is weak and vulnerable. Generally, government organizations are more responsive for preparing the shelter center.

On the basis of affected people perception, most of the respondents $(43.9 \%)$ have argued that the government organizations play an effective role regarding the preparation of shelter center where $33.9 \%$ respondents have argued that non-government organization plays an effective role regarding this. Rest $22.2 \%$ of respondents have opined that both of the organizations play their role effectively regarding the preparation of shelter center. There are some exceptional cases where NGOs role is very effective regarding preparation of shelter center. South Ullah can be the example for this where $49.3 \%$ of respondents think that NGOs play an effective role for preparation of shelter center before the disaster.

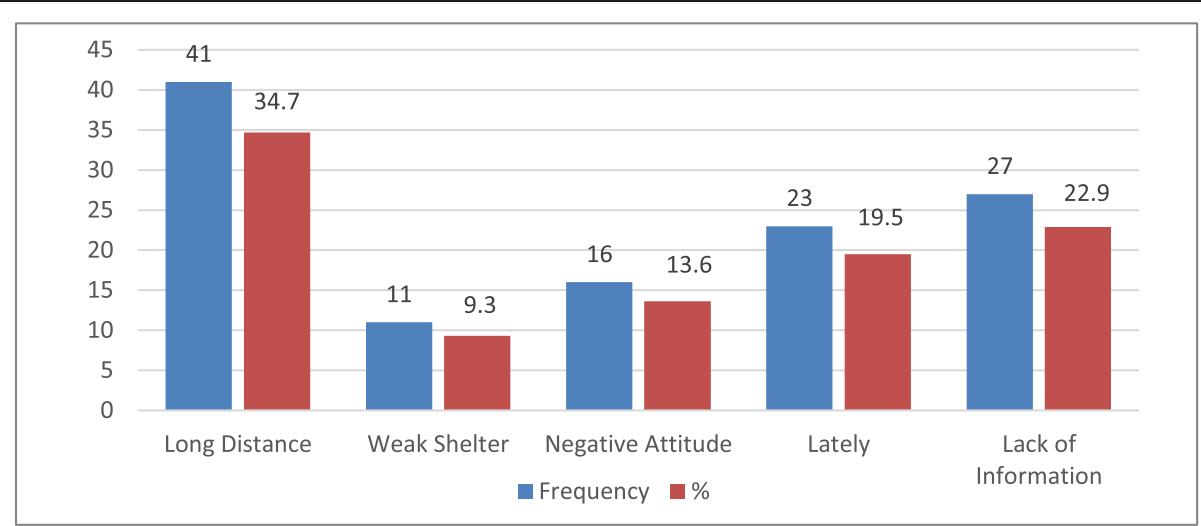

Fig. 3 Reason for not going to Shelter Center. Source: Field Survey June-September, 2018, December, 2018-April, 2019 
Table 3 Initiatives taken by organizations for preparedness effectively

\begin{tabular}{|c|c|c|c|c|c|c|c|c|}
\hline \multirow[t]{2}{*}{ Initiatives } & \multicolumn{6}{|c|}{ Type of Organization and Percentage } & \multicolumn{2}{|c|}{ Total } \\
\hline & GOs & $\%$ & NGOs & $\%$ & Both & $\%$ & $\mathbf{N}$ & $\%$ \\
\hline Preparatory Meeting & 169 & 53.0 & 108 & 33.9 & 42 & 13.1 & 319 & 100 \\
\hline Training Program & 69 & 21.6 & 175 & 54.9 & 75 & 23.5 & 319 & 100 \\
\hline Preparing Shelter & 140 & 43.9 & 108 & 33.9 & 71 & 22.2 & 319 & 100 \\
\hline Medical Preparation & 94 & 29.5 & 161 & 50.5 & 64 & 20.0 & 319 & 100 \\
\hline
\end{tabular}

Source: Field Survey June-September, 2018, December, 2018-April, 2019

After flood disaster, because of the unavailability of a medical facility, affected people suffer in many ways. Including first aid facilities, several types of medical facilities are needed for the affected people. Service providing organizations can come forward within very short possible time if they remain prepared. Concerning medical preparation, $29.5 \%$ of respondents think that the government organizations remain more prepared for providing services where $50.5 \%$ of respondents believe that non-government organizations remain more prepared for providing services and $20.0 \%$ of respondents figure out that both organizations remain prepared according to the ability.

\section{Emergency response: a review of performance of GOs and NGOs}

Recovery can be parted into two individual phases, each by way of distinct actions: short-term and long-term. The short-term recovery period immediately monitors the disaster event, while emergency response activities are underway. Short-term regaining activities try to steady victims' lives by preparing them for a long road toward restructuring. These actions often considered as reactive actions or termed "relief," include temporary shelter arrangements, emergency food and water distribution, critical infrastructure restoration, and debris disposal. Short-term retrieval activities tend to be impermanent and often do not always directly avail to the actual long-term progress of the community. By the following sub-section, a short-term (which started from the flood and lasted for 6 months) recovery activity done by GOs and NGOs has been discussed on people's perception.

\section{People's perception regarding rescue and relief}

When the extreme flood-hit a region, at that time all houses inundate due to intrusion of flood water. Then the trapped people leave their homes as soon as possible and need to take shelter to save their life such as near the highway, school, and flood shelter centers. Along with organizations, local people created a group by their next-door neighbor during the flood of 2017. At first, both rescue teams give pay attention on the children and older people concerning their safety. Because children and older people are more fragile during the flood for this reason, they sent them to safer flood-free places.

Rescue of family members (during 2017 flood) Rescue operation may not always be needed, but in some special cases, it is very important. Table 4 shows that family members of $19.7 \%$ of respondents were rescued during the fatal 2017 flood with the help of local people and government and non-government organizations. Among the rescued people, more than $50 \%$ were rescued by GOs.

During the interview session, Project Implementation Officer (PIO) of Saghatta Upazila has explained that among the NGOs 'SKS' played a vital role in the emergency rescue operation at South Ullah under Bhartkhali Union. On the other hand, PIO of both Upazila has opined that local people were very much cooperative with GOs and NGOs in this respect. Findings show that GOs and neighbors of the respondents played a mentionable role to rescue the affected people who were bounded by the sudden water.

Relief received from organizations during the emergency period The Fig. 4 illustrates that among the respondents, $56.7 \%$ received aid from government relief Program where $43.3 \%$ of respondents did not get any type of aid. Some of the respondents who did not get any assistance from government organizations

Table 4 Status of rescue operation during 2017 flood

\begin{tabular}{lll}
\hline & Frequency & $\%$ \\
\hline Response about rescue & & \\
Yes & 63 & 19.7 \\
No & 256 & 80.3 \\
Total & 319 & 100 \\
Rescuer & & \\
GOs & 32 & 50.8 \\
NGOs & 16 & 25.4 \\
Neighbor & 15 & 23.8 \\
Total & 63 & 100 \\
\hline
\end{tabular}

Source: Field Survey June-September, 2018, December, 2018-April, 2019 


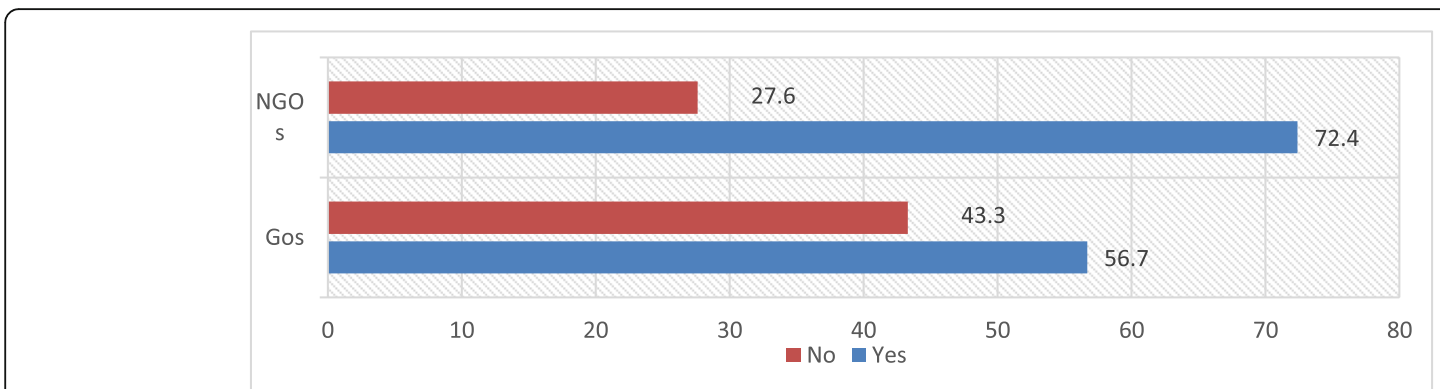

Fig. 4 Distribution of the respondents by receiving emergency aid. Source: Field Survey June-September, 2018, December, 2018-April, 2019

demanded that they had needed but did not get. On the other hand, among the respondents, $72.4 \%$ received aid from non-government relief program where $27.6 \%$ of respondents did not get any type of aid. Findings show that coverage of NGOs was higher than the GOs. Respondents also demanded that the quality and quantity of aid of NGOs were better than the aid of GOs.

Main item of relief received from organizations Just after occurring of the flood disaster, affected people need several types of help as they lose almost everything. People from all walks of life come forward to help distressed people with the government. The Government tries to play its expected role through its various agencies and organizations. By Table 5, the researcher has attempted to represent the position of government organizations and non-government organizations on the basis of providing the main item of relief.

The Table 5 shows that out of total respondents 53.6\% of respondents received food item, $11.4 \%$ water, $22.9 \%$ cloth, $17.9 \%$ medicine, $36.7 \%$ cash, $17.9 \%$ CI sheet and $8.2 \%$ other facilities from GOs and from NGOs Out of total respondents $74.3 \%$ received food, $52.4 \%$ received pure drinking water, $39.8 \%$ received cloth, $57.9 \%$ medicine, $10.3 \%$ cash, CI sheet $3.1 \%$ and $24.8 \%$ received other facilities. The organizations particularly emphasize on

Table $\mathbf{5}$ Item of relief received by the respondents from organizations

\begin{tabular}{|c|c|c|c|c|}
\hline \multirow{2}{*}{$\begin{array}{l}\text { Item of } \\
\text { Relief }\end{array}$} & \multicolumn{2}{|l|}{ GOs } & \multicolumn{2}{|l|}{ NGOs } \\
\hline & Frequency $(N=319)$ & $\%$ & Frequency $(N=319)$ & $\%$ \\
\hline Food & 171 & 53.6 & 237 & 74.3 \\
\hline Water & 37 & 11.4 & 167 & 52.4 \\
\hline Cloth & 73 & 22.9 & 127 & 39.8 \\
\hline Medicine & 57 & 17.9 & 184 & 57.9 \\
\hline Cash & 117 & 36.7 & 33 & 10.3 \\
\hline Cl Sheet & 57 & 17.9 & 10 & 3.1 \\
\hline Others & 26 & 8.2 & 79 & 24.8 \\
\hline
\end{tabular}

Source: Field Survey June-September, 2018, December 2018-April, 2019 (Multiple Responses have been Considered) food items where mainly organizations separated into food and non-food items as relief delivery. In the flood of 2017, the GOs and NGOs provided rice, pulse, edible oil, iodized salt, sugar, baby cereal etc. as food items, and these kinds of items delivered into various food package. On the contrary, CI Sheet, Blankets, Shari, Lungi, Mosquito net, rope, family kit, kitchen Set, ORS pkts, bucket and mug, soap, sanitary pad, washing powder were the main items of non-food as relief.

It can clearly be said that GOs played a comparatively better role by providing cash money and CI (Corrugated Iron) Sheet. On the other hand, NGOs played a comparatively better role by providing food, water, cloth, and medicine.

\section{Amount of financial help from organizations as relief} After the devastating flood disaster in 2017, losing all the belongings of the affected people, including their professional and livelihood materials- such as plow and cattle, boats and nets, they were completely helpless, jobless and their miseries knew no bound. Besides, Organizations also gave pay attention to deliver monetary help as relief for temporary housing, dead parson, flood insurance and so on. The government and nongovernment organizations tried to provide monetary help with all types of necessary goods. Table 6 shows the condition of monetary help during the emergency period.

In analyzing the group of respondents based on the amount of cash received, it is evident that $15.7 \%$ of respondents received Tk. 2001 to 4000 as relief from GOs which is the highest among all groups and $15.0 \%$ of respondents received Tk. 4001 to 6000 which comes after the former group. GOs provide monetary help in excess of Tk. 6000 to very few respondents. In the case of NGOs, the scenario is slightly different. The largest number of respondents (14 or 4.4\%) received monetary help between Tk. 1 to 2000 in case of NGOs out of total respondents. The number of respondents who received monetary help between Tk. 2001 to 4000 is 11 or $3.4 \%$ which comes after the previous group. NGOs did not provide monetary help to any respondent in excess of 
Table 6 Distribution of the respondents by financial help as relief

\begin{tabular}{llllll}
\hline $\begin{array}{llllll}\text { Amount of } \\
\text { cash }\end{array}$ & GOs & & & NGOs \\
\cline { 2 - 3 } & Frequency $(\boldsymbol{N}=\mathbf{1 1 7})$ & $\%$ & & Frequency $(\boldsymbol{N}=\mathbf{3 3})$ & $\%$ \\
\hline $0001-2000$ & 11 & 3.4 & 14 & 4.4 \\
$2001-4000$ & 50 & 15.7 & 11 & 3.4 \\
$4001-6000$ & 48 & 15.0 & 8 & 2.5 \\
$6001-8000$ & 3 & .9 & 0 & 0.0 \\
$8001-10,000$ & 5 & 1.6 & 0 & 0.0 \\
Obtained & 117 & 36.7 & 33 & 10.3 \\
Could not get & 202 & 63.3 & 286 & 89.7 \\
Total & 319 & 100 & 319 & 100.0 \\
\hline
\end{tabular}

Source: Field Survey June-September, 2018, December, 2018-April, 2019 Note: Taka $(\mathrm{BDT})=$ Bangladesh Taka, approximately Tk. $84=$ US\$1 in these years

Tk. 6000 during emergency response. One important feature of the above table is that monetary coverage of NGOs is comparatively low than GOs both in terms of amount of cash and number of recipients. From the above discussion, it is observed that the proportion of respondents getting monetary help out of total respondents was very low in the case of NGOs, but in the case of GOs, the scenario was completely different. In respect to GOs, the proportion was $36.7 \%$ whereas that of NGOs was only $10.3 \%$ out of total respondents.

Provision of agricultural production materials Bangladesh is mainly an agricultural based country where almost $80 \%$ of people are directly and indirectly relating to agriculture. Thus, most of the people in our agro-based society are engaged with several types of cultivation, and the char land area is no exception. However, the number of crop losers is very high, and the amount of losses is also very high. Observation showed that almost all households confronted crop loss fully due to extreme flood in 2017.

The local people usually select cropland to cultivate after the floodwater gone away. Sometimes they cannot cultivate due to seeds and agricultural materials. Concerning this, government and non-government organizations come forward to help the severely affected farmers in the post-flood for providing seeds and materials. For better agricultural support, seed, fertilizer, and equipment are very much important. No farmer can restart their farming without these important items.

From Table 7 , there were $36.1 \%$ of respondents received seed from GOs, 263.5\% from NGOs, and 8.4\% from both GOs and NGOs. The beneficiaries were supported for home-gardening in order to ensure nutrition and reduced malnutrition. Observation shows that the majority of small, marginal sharecropping farmers had lost their seeds. So, the seeds of eggplant, bottle gourd, spinach, carrot, radish, tomato, beetroot, spinach, okra, gima kalmi, red pumpkin, ash gourd, amaranth, chilly, bitter gourd, and papaya were provided among the affected people who were engaged in farming. The above table also shows that regarding fertilizer, $60.5 \%$ of respondents received fertilizer from only GOs and the rest $39.5 \%$ did not receive any fertilizer. Government and non-government organizations tried to provide important equipment to the farmer regarding equipment, $12.9 \%$ of respondents received equipment from GOs, 9.1\% from NGOs and $4.0 \%$ of respondents received equipment both from GOs and NGOs. Findings of the above Table 7 display that GOs played a vital role in providing seed, fertilizer, and agricultural equipment than NGOs.

\section{Restoration program provided by organizations after 2017 flood}

Just after the occurrence of the devastating 2017 flood disaster, to protect overall environmental degradation and to develop a communication system, several types of initiatives had been taken by the government and non-government organizations. Since the total system was collapsed among the study areas, government and non-government organizations started their operations to restore the whole system with food and non-food relief item. It was found from the participant observation and interviews that GOs and NGOs gave emphasis especially for the household development including local infrastructure improvement where GOs repairing 4 $\mathrm{km}$ rural earthen road, one educational institution, five (5) tube well and two dams; raising of 35 house plinth, one education's field, and countless removal of garbage from the villages as well as setting new latrine (25). On the contrary, NGOs were engaged

Table 7 Agricultural assistance as relief from GOs \& NGOs ( $N=319)$

\begin{tabular}{|c|c|c|c|c|c|c|c|c|}
\hline \multirow{2}{*}{$\begin{array}{l}\text { Type of } \\
\text { help }\end{array}$} & \multicolumn{2}{|l|}{ GOs } & \multicolumn{2}{|l|}{ NGOs } & \multicolumn{2}{|l|}{ Both } & \multicolumn{2}{|l|}{ Did not Get } \\
\hline & Frequency & $\%$ & Frequency & $\%$ & Frequency & $\%$ & Frequency & $\%$ \\
\hline Seed/plant & 115 & 36.1 & 75 & 23.5 & 27 & 8.4 & 102 & 32.0 \\
\hline Fertilizer & 193 & 60.5 & 0 & 0 & 0 & 0 & 126 & 39.5 \\
\hline Equipment & 41 & 12.9 & 29 & 9.1 & 13 & 4.0 & 236 & 74.0 \\
\hline
\end{tabular}

Source: Field Survey June-September, 2018, December, 2018-April, 2019 
mainly $5 \mathrm{~km}$ rural road repaired, reconstruction 12 tube well, raised 94 house plinths, setting 40 new latrines, cleaned 5 ponds, and countless medical support.

\section{Problem and experience of the affected people}

In the flood-prone zone particularly in the char land of Bangladesh, almost every year most of the people face several types of problems caused by the flood disaster and gather bitter experience. The poor and vulnerable people (Affected People) face several types of problems to get services from the service providers. With some severe problems, the disaster affected people in the study area gather several types of experiences concerning getting information, taking shelter in the shelter center during the disaster and after the disaster, receiving emergency relief, medical facilities, monetary help, etc.

\section{Problems of the affected people}

Problems of the affected people have been discussed on preparedness and emergency response including some sub-heads. The types of problems faced after the flood in 2017 by the affected people to get services from the organizations have been discussed. Almost in all steps, the 2017 flood-affected people faced several types of problems that need to be discussed on the following heads to reveal the problems of affected people.

During preparedness Information is very much significant for the disaster affected people to save the lives and assets from the flood disaster when the flood-hit. By getting disaster-related information properly, everybody can get enough time to go to the shelter center or safe side and can save their valuable goods. The Table 8 shows that the problems regarding receiving information. From the table, it is seen that among the respondents, $40.8 \%$ faced problems to get disaster-related information, and $59.2 \%$ did not face any type of problem to get information.

Again, among the respondents who faced problems (130) to get information, out of them $13.1 \%$ think that lack of coordination is the main problem for not getting information whereas according to $21.5 \%$ of respondents, taking initiatives lately is the main problem. On the other hand, $26.9 \%$ of respondents think that officials are not sincere to announce the information and $38.5 \%$ think that equipment (Cyrene, Radio, etc.) are not sufficient to announce the disaster-related information in time. Findings of the Table 8 illustrate that most of the respondents get disaster-related information in time without facing any problem and it also shows the organizational capability for the dissemination of the information. And at the same time, the paucity of equipment and the insincerity of the officials are also seen as the barriers for the affected people to receive disasterrelated information.

During the disaster period, taking shelter in the shelter center is very essential for saving the lives of the affected people who are vulnerable or risky positions in the flood-prone zone of the country. Evacuation and giving shelter are very important to the affected people and service providers to save the lives, but both the affected people and service providers face some problems regarding taking shelter in the shelter center. The Fig. 7 illustrates the problems faced by the affected people regarding shelter in the shelter center during the disaster period.

From the Fig. 5, it can be seen that most of the respondents (53.9\%) faced problems regarding shelter in the shelter center where $47.1 \%$ of respondents did not face any problem regarding this. Among the respondents who faced problems out of them 23.8, 18, 16.3, 32 , and $9.9 \%$ faced problems due to long-distance, weak shelter centers, lack of information, homesickness and taking initiatives lately respectively. Findings of the Fig. 5 show that most of the respondents (53.9\%) faced problem regarding taking shelter in the shelter center during the disaster and among them a significant number of the respondents (23.8 \& 32\%) did not go to the shelter center due to long-distance and homesickness.

For the period of rescue and relief In the flood-prone zone of Bangladesh when flood disaster hit, the rescue program gets the highest priority to the organizations. With the organizations, the local people also help to

Table 8 Problems regarding receiving information

\begin{tabular}{|c|c|c|c|c|c|}
\hline Categories & Variable & $f$ & $\mathbf{N}$ & $\%$ & Total \% \\
\hline \multirow[t]{2}{*}{ Status of facing problem } & Yes & 130 & 319 & 40.8 & 100 \\
\hline & No & 189 & & 59.2 & \\
\hline \multirow[t]{4}{*}{ Types of problems } & Lack of Coordination & 17 & 130 & 13.1 & 100 \\
\hline & Taking Initiatives Lately & 28 & & 21.5 & \\
\hline & Insincerity of Officials & 35 & & 26.9 & \\
\hline & Lack of Equipment (Cyrene, Radio etc.) & 50 & & 38.5 & \\
\hline
\end{tabular}




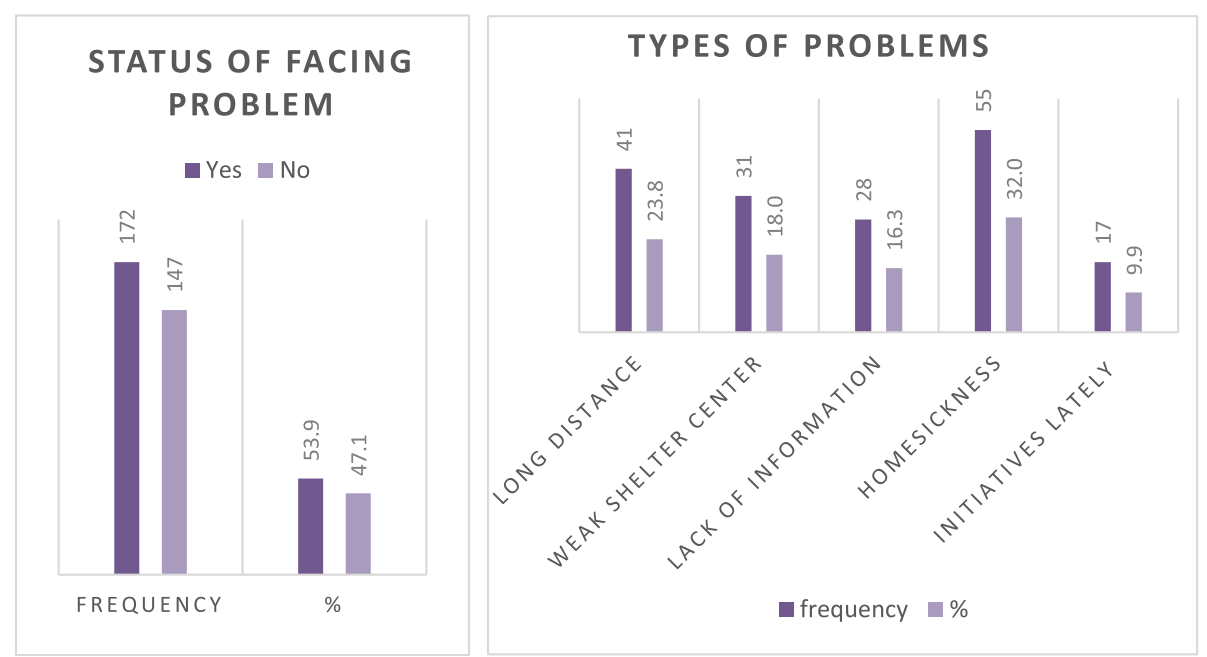

Fig. 5 Problems in taking shelter in Shelter Center. Source: Field Survey June-September, 2018, December, 2018-April, 2019

rescue the victims. According to the respondents, there are some barriers to the rescue operation. The Table 8 demonstrates the main obstacle of the rescue program in the study area during the devastating flood in 2017.

Among the respondents from the beneficiary, $16.3 \%$ have pointed out that lack of logistic support is the main barrier to the rescue program. $44.2 \%$ have viewed that under developed communication system is another problem, because the study villages are basically char (island) which is entirely disconnected from the mainland. For this reason, there is no convenient direct way to communicate with the mainland. In the normal period like the dry season, people are used to communicating with the mainland by walking, and for carrying heavy goods using horse carriage. During the high flood like 2017, the means of transportation worsened automatically, and the infrastructure couldn't able to support it due to the high floodwater stream as well as riverbank erosion. Therefore, the service provider could not execute rescue program properly. $26.6 \%$ of beneficiaries have argued that lack of suitable vehicle is the main barrier and the rest of $12.9 \%$ have opined that lack of trained manpower is the main barrier. From the Table 9, according to the highest portion of the respondents, under developed communication system is the main problem considering rescue program. One of the KII (Key Informant Interviews) also has argued in favor of under developed communication systems. He has opined that most of the rural area of flood-prone/Char zone are underdeveloped and condition of roads are not very good, in addition, most of them are kutcha (muddy) as well as water surrounded.

Providing adequate food, water and medication are very important to support the affected people, but there were some obstacles to get relief in the emergency period after the 2017 flood. The Table 10 shows the main obstacle to get relief according to the respondents. $11.6 \%$ of respondents have viewed that wastage of time is the main obstacle to get relief and $16.6 \%$ have argued that communication is the main obstacle.

The highest numbers of the respondents (27.9\%) have opined that insufficiency is the main obstacle to get relief. Standing a lot of time, when the affected people do not get the minimum desired amount, they become shocked very much. According to $21.0 \%, 14.4 \%$, and $8.5 \%$ of respondents, political influence, nepotism, and corruption are the main obstacle to get relief, respectively. According to the above data, only $21.0 \%$ respondents have viewed that political influence was the main barrier to get relief in the emergency period after the flood in 2017, but the observation shows that political influence were the main obstacles to the most of the affected people in the study area at present.

There are some influential persons in society who have enough influence on society. They also have enough capacity to exercise power to control society positively. If the influential persons try to influence the wellbeing of the society, they can do that, but for the self-interest sometimes they become part of unfair means.

Table 9 Main barrier of rescue program

\begin{tabular}{lll}
\hline Main barrier of rescue program & Frequency & $\%$ \\
\hline Lack of logistic support & 52 & 16.3 \\
Under developed communication system & 141 & 44.2 \\
Lack of suitable vehicle & 85 & 26.6 \\
Lack of trained manpower & 41 & 12.9 \\
Total & 319 & 100.0 \\
\hline
\end{tabular}

Source: Field Survey June-September, 2018, December, 2018-April, 2019 
Table 10 Distribution of the respondents by the obstacle to get relief

\begin{tabular}{lll}
\hline Main obstacle to get relief & Frequency & $\%$ \\
\hline Wastage of time & 37 & 11.6 \\
Communication & 53 & 16.6 \\
Insufficiency & 89 & 27.9 \\
Political influence & 67 & 21.0 \\
Nepotism & 46 & 14.4 \\
Corruption & 27 & 8.5 \\
Total & 319 & 100.0
\end{tabular}

Source: Field Survey June-September, 2018, December, 2018-April, 2019 role respectively. It is significant that according to most of the respondents, the government organizations could not play the expected role regarding preparedness.

On the other hand, people's perception was more positive to non-government organizations than government organizations. $15.8 \%$ of respondents think that NGOs played a very good role where $31.0,32.0,13.7$, and $7.5 \%$ believe that non-government organizations played good, average, bad and very bad role respectively for preparedness. Figure 6 shows that according to the highest number of respondents, the non-government organizations could play an expected role regarding preparedness.

\section{Experience regarding relief}

Sufficient relief materials help to restore the condition of affected people after any natural disaster. The government and non-government organizations try to provide sufficient relief materials overcoming the limitations in time of need. The following table describes the opinion of the affected people regarding the sufficiency of relief material obtained from GOs and NGOs.

Among the total respondents, only 5.6\% think that relief material provided by GOs was very sufficient whereas $23.8 \%$ believe that relief material provided by NGOs was very sufficient. Again, $14.1 \%$ believe that relief material provided by GOs was sufficient whereas $26.4 \%$ think that relief material provided by NGOs was sufficient. The highest number of respondents $(32 \%$, 102) thinks that relief material provided by GOs was very insufficient whereas only $5.6 \%$ of respondents believe that relief material provided by NGOs was very insufficient. From the Fig. 7, it has been revealed that NGOs provided enough relief material to the flood in 2017 affected people than GOs.

From a formal and informal interview with the flood disaster-affected people in the study area, it has been found that satisfaction depends on obtaining relief, quality and quantity of relief, time of receiving relief, etc. Most of the affected people received relief (cash, food and non-food item) from GOs or NGOs or both GOs and NGOs. The Fig. 8 shows the level of satisfaction of the respondents for getting relief material from government and non-government organizations.

The Fig. 8 shows that regarding GOs relief, only $6.6 \%$ of respondents were very satisfied and $16.3 \%$ of respondents were satisfied whereas regarding NGOs' relief, $29.5 \%$ were satisfied and $24.7 \%$ of respondents were very satisfied in terms of quality, quantity and time of receiving emergency relief. Again, regarding GOs relief, 28.8\% of respondents were unsatisfied, and $30.2 \%$ of respondents were very unsatisfied, but regarding NGOs, $12.2 \%$ of respondents were unsatisfied, and only $4.7 \%$ of respondents were very unsatisfied. So, based on the

Source: Field Survey June-September, 2018, December, 2018-April, 2019

aLocal People Representatives

${ }^{b}$ Local Political leader 

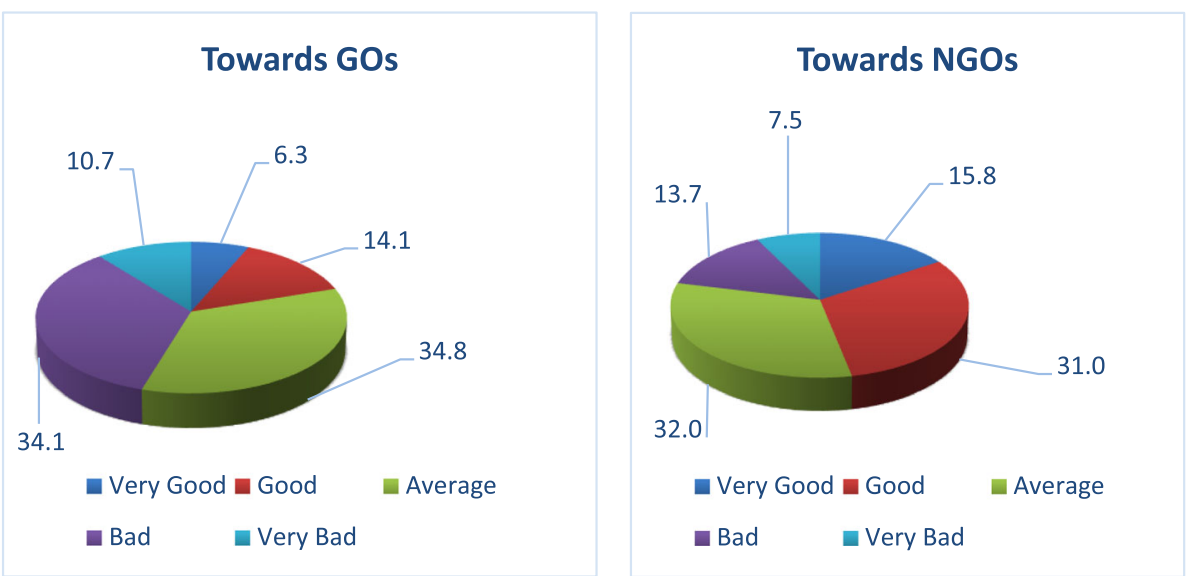

Fig. 6 Experiences regarding organizational initiatives for preparedness. Source: Field Survey June-September, 2018, December, 2018-April, 2019

respondent's perception, it can be said that the level of satisfaction towards NGOs was higher than the GOs.

\section{Conclusion and recommendations}

Flood disaster is a frequent phenomenon in the study villages, for this reason, the dwellers depend on the aids of government organizations and non-government organizations to cope with the overwhelming situation since they lose almost everything. As such the GOs and NGOs provided their services as part of preparedness and emergency response during the 2017 flood period. Both the GOs and NGOs showed their outstanding performance with respect to disseminate information. Most of the respondents $(93.7 \%)$ received information before the disaster, and the main way of getting information was announcing through loud speakers by GOs and NGOs. Also, they played a very effective role regarding initiatives for preparedness. GOs arranged preparatory meetings and prepare shelter centers very effectively, whereas
NGOs organized training programs very successfully. Organizations were very prompt for rescue and relief programs. Just after the occurrence of the 2017 flood, GOs played a very efficient and expected role providing CI Sheet and monetary help, whereas; NGOs played a very applicable and expected role providing food relief, medical and IGA facilities, etc. In respect to restoration program, selected NGOs performed an extraordinary job which attracted the people's concentration. Besides, while receiving service about rehabilitation facilities, the disaster affected people faced several problems and faced bitter experience. Because of corruption, nepotism, improper assessment, and difficult procedure, affected people did not get rehabilitation facilities properly. On the basis of the objectives and found results of the study and the overall situation of the role of organizations regarding preparedness and emergency response of the flood disaster-affected people, the researcher has proposed some subjects to address this study.
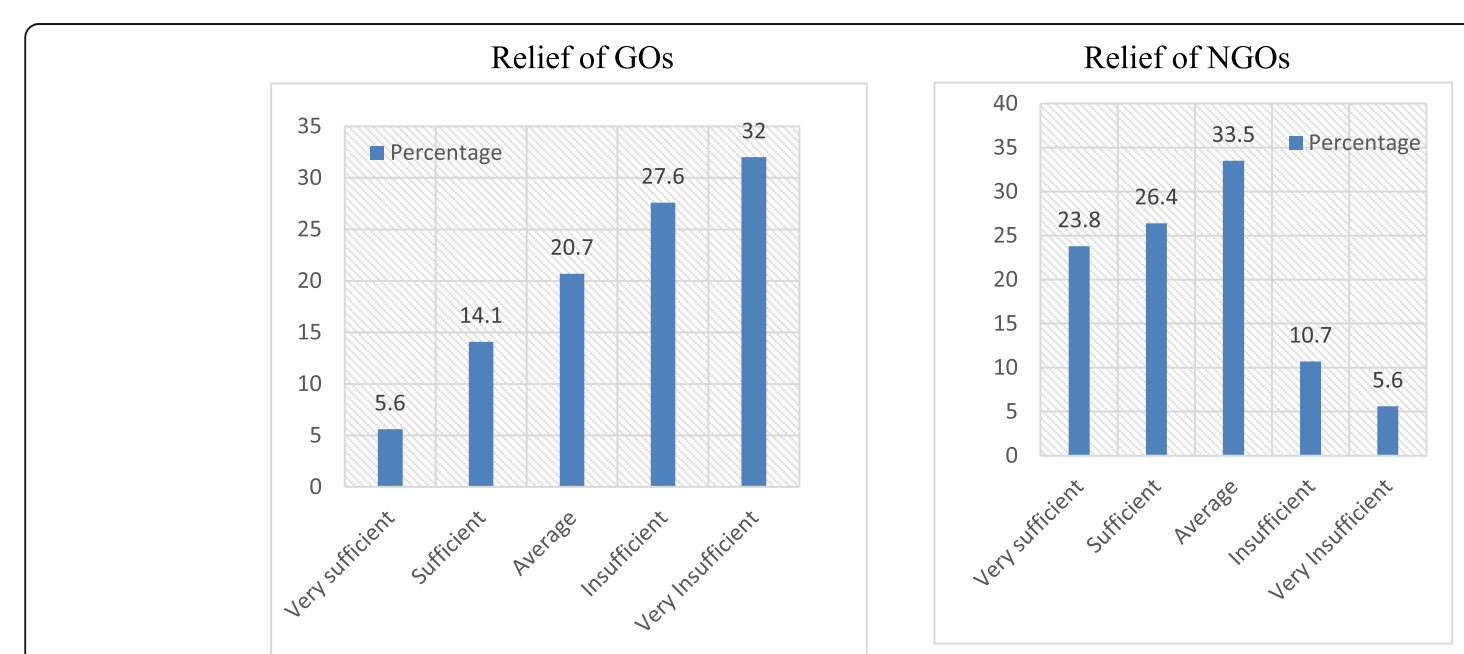

Fig. 7 Experience regarding sufficiency of obtained relief. Source: Field Survey June-September, 2018, December 2018-April, 2019 

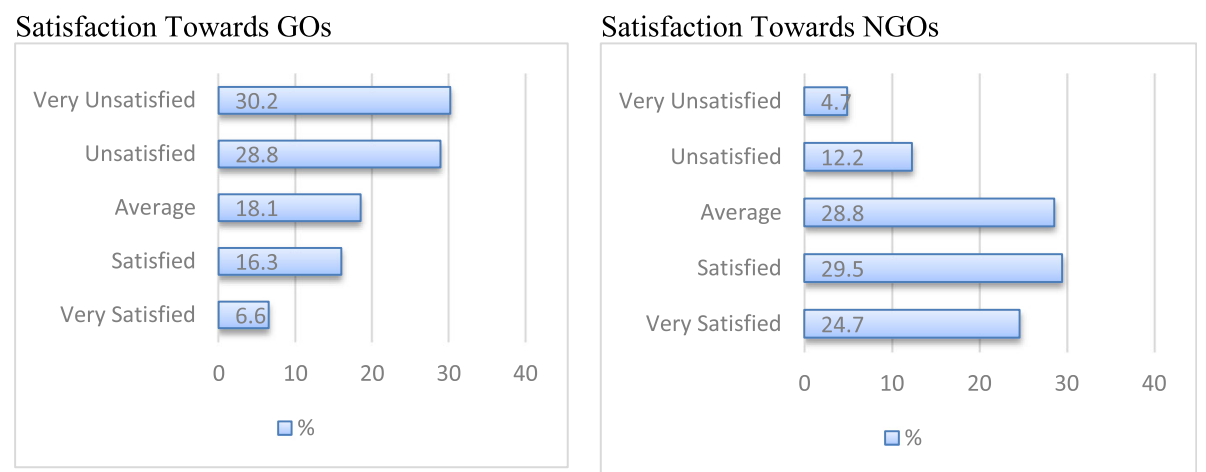

Fig. 8 People's satisfaction regarding relief from organizations. Source: Field Survey June-September, 2018, December, 2018-April, 2019

I Along with public participation, organizations should work collectively in the flood crisis period because the present study found out that the lack of local people participation as a main gap in flood management activities.

J NGOs should provide more financial help as relief avoiding difficult procedures for the affected people. On the other hand, Organizations should make available financial help as loan for regaining the IGA facilities within a short possible of time as most of the char land people lose their IGA facilities which are very much related to the livelihood of the affected people.

$\mathrm{K}$ In addition, existing flood shelter centers can serve a small number of the population in the study area. Therefore, setting up of multipurpose flood shelters is essential, and at least two storied new schools should be built on flood-free highlands so that villagers are less vulnerable to impending floods. Moreover, training and awareness programs on flood preparedness should be more concentrated and steadier.

L For easy and smooth relief distribution, all kinds of complicated processes from the center to the grassroots level should be avoided. Therefore, corruption, nepotism and political and local interventions should be eliminated to ensure equal and fair distribution of relief goods among flood disaster victims, and the organizations may also increase monitoring and supervision to ensure relief and equitable rehabilitation.

M Along with short-term rehabilitation, organizations should give concern about long-term rehabilitation. Because of this path can give prosperity to cope with the adverse situation. Therefore, for long-term rehabilitation or recovery, the government and nongovernment organizations should begin to rebuild the infrastructure in the affected area for the general people and rehabilitate the affected defenseless people for sustainable development. It lasts for years for major flood disasters, so organizations should be more emphasized with respect to financial assistance, housing reconstruction, IGA facilities and new work opportunities beyond localities. In which, financial help is very helpful and important for the overall development of the disaster affected people. The government and non-government organizations should provide financial help for various purposes with several terms and conditions. Affected people who are very much sincere and conscious; they can change their social position using obtained financial help efficiently. Because all types of income-generating activities (IGA) are basically dependent on financial help.

\footnotetext{
Acknowledgments

I would like to express my sincere appreciation to my study respondents who were patient interviewees and provided necessary information for this study. I shall never forget their sincere cooperation and support.
}

\section{Author's contributions}

Corresponding author $\mathrm{BH}$ carried out the study, performed the statistical analysis, wrote the protocol, and wrote the draft of the manuscript. The author(s) read and approved the final manuscript.

\section{Funding}

Not applicable' for that section.

\section{Availability of data and materials}

The data sets used and analyzed during the current study are available from the corresponding author on request.

\section{Competing interests}

The author declares that there is no competing of interest.

Received: 2 March 2020 Accepted: 13 October 2020

Published online: 25 November 2020

\section{References}

Adnan S (1991) Floods, people and the environment: institutional aspects of flood protection programmes in Bangladesh, 1990

Alcántara-Ayala I (2002) Geomorphology, natural hazards, vulnerability and prevention of natural disasters in developing countries. Geomorphology 47(2-4):107-124 
Aminuzzaman S (2000) Institutional framework of poverty alleviation: an overview of Bangladesh experiences. Paper presented at the Development Studies Network Conference on Poverty, Prosperity and Progress

Bank W (1996) Pursuing common goals: strengthening relations between government and development NGOs. World Bank Resident Mission, Dhaka

Blair H (2005) Civil society and propoor initiatives in rural Bangladesh: finding a workable strategy. World Dev 33(6):921-936

Brammer H (1990) Floods in Bangladesh: II. Flood mitigation and environmental aspects. Geogr J 156:158-165

Brouwer R et al (2007) Socioeconomic vulnerability and adaptation to environmental risk: a case study of climate change and flooding in Bangladesh. Risk Anal 27(2):313-326

Burton L, Kates R, White G (1993) The environment as hazard, 2nd edn. Guilford Press, New York

Cannon T (1994) Vulnerability analysis and the explanation of 'natural'disasters. Disasters Dev Environ 1:13-30

Cannon T, Twigg J, Rowell J (2003) Social vulnerability, sustainable livelihoods and disasters. Report to DFID conflict and humanitarian assistance department (CHAD) and sustainable livelihoods support office, 93

Choudhury AMEA (2005) Socio-economic and physical perspectives of water related vulnerability to climate change: results of field study in Bangladesh. Sci Cult 71(7/8):225

Coppola DP (2006) Introduction to international disaster management. Elsevier Amsterdam

Del Ninno C, Dorosh PA, Smith LC (2003) Public policy, markets and household coping strategies in Bangladesh: avoiding a food security crisis following the 1998 floods. World Dev 31(7):1221-1238

Dun O (2011) Migration and displacement triggered by floods in the Mekong Delta. Int Migr 49:e200-e223

Few R (2003) Flooding, vulnerability and coping strategies: local responses to a global threat. Prog Dev Stud 3(1):43-58

Gray CL, Mueller V (2012) Natural disasters and population mobility in Bangladesh. Proc Natl Acad Sci 109(16):6000-6005

Hasan Z et al (2013) Challenges of integrating disaster risk management and climate change adaptation policies at the national level: Bangladesh as a case. Glob J Hum Soc Sci Geogr Geo-Sci Environ Disaster Manag 13(4):54-65

Hoque MM, Siddique MA (1995) Flood control projects in Bangladesh: reasons for failure and recommendations for improvement. In: Institute of flood control and drainage research. BUET, Dhaka

Hossain B, Ajiang C, Ryakitimbo CM (2019) Responses to flood disaster: use of indigenous knowledge and adaptation strategies in Char Village, Bangladesh. Environ Manage Sustainable Dev 8(4):46-74. https://doi.org/10.5296/emsd.v8i4.15233

Hossain MZ, Sakai T (2008) Severity of flood embankments in Bangladesh and its remedial approach. Agricultural Engineering International: the CIGR Ejournal. Manuscript LW 08 004. Vol. X.

Hossain MA (2012) Community participation in disaster management: role of social work to enhance participation. Sociology 159:171

Howell P (2003) Indigenous early warning indicators of cyclones: potential application in coastal Bangladesh. Benfield Greig Hazard Research Centre, London

Ibrahim NF et al (2017) Identification of vulnerable areas to floods in Kelantan River sub-basins by using flood vulnerability index. Int J GEOMATE 12(29):107-114

ISDR (2006) NGOs \& disaster risk reduction: a preliminary review of initiatives and progress made. ISDR, Geneva

Islam MR (2018) Climate change, natural disasters and socioeconomic livelihood vulnerabilities: migration decision among the char land people in Bangladesh. Soc Indic Res 136(2):575-593

Islam MR et al (2018) From coping to adaptation: flooding and the role of local knowledge in Bangladesh. Int J Disaster Risk Reduction 28:531-538

Islam SN et al (2010) Settlement relocations in the char-lands of Padma River basin in Ganges delta, Bangladesh. Front Earth Sci China 4(4):393-402

Kafi MAH, Chowdhury ASMT (2010) Probable Impact of Climate Change of Flood in Bangladesh. IWFM - BUET, Dhaka, Bangladesh.

Kelly C, Chowdhury MK (2002) Poverty, disasters and the environment in Bangladesh: a quantitative and qualitative assessment of causal linkages. Bangladesh Issues Paper. UK Department for International Development, Dhaka

Kothari CR (2004) Research methodology: methods and techniques. New Age International, New Delhi

Likert R (1932) A technique for the measurement of attitudes. Arch Psychol 140:55-60 Management DOD (2007) Flood in 2017 updated, Bangladesh (http://uww.ddm.gov.bd)
Matin N, Taher M (2001) The changing emphasis of disasters in Bangladesh NGOs. Disasters 25(3):227-239

Mirza MMQ (2002) Global warming and changes in the probability of occurrence of floods in Bangladesh and implications. Glob Environ Chang 12(2):127-138

Mondal MS et al (2015) Hydro-climatic hazards for crops and cropping system in the chars of the Jamuna River and potential adaptation options. Nat Hazards 76(3):1431-1455

Mutton D, Haque CE (2004) Human vulnerability, dislocation and resettlement: adaptation processes of river-bank erosion-induced displacees in Bangladesh. Disasters 28(1):41-62

Nirapad (2017) Flood situation updated on august 22 (http://www.nirapad.org.bd/)

Nur I, Shrestha KK (2017) An integrative perspective on community vulnerability to flooding in cities of developing countries. Process Eng 198:958-967

Paul BK, Rasid H (1993) Flood damage to rice crop in Bangladesh. Geogr Rev 83:150-159

Paul S, Islam MR (2015) Ultra-poor char people's rights to development and accessibility to public services: a case of Bangladesh. Habitat Int 48:113-121

Paul SK, Hossain MN (2013) People's perception about flood disaster management in Bangladesh: a case study on the Chalan Beel area. Stamford J Environ Hum Habitat 2:72-86

Paul SK, Routray JK (2010) Flood proneness and coping strategies: the experiences of two villages in Bangladesh. Disasters 34(2):489-508

Philip S et al (2019) Attributing the 2017 Bangladesh floods from meteorological and hydrological perspectives. Hydrol Earth Syst Sci 23(3):1409-29

Portal BN (2018) Kurigram District BNP (http://www.kurigram.gov.bd)

Relief MODMA (2013) Diseaster report Dhaka: Department of Disaster Management, 2014, p 22

Shajahanl AARMY (2001) Towards sustainable flood mitigation strategies: a case study of Bangladesh. Department of Architecture, BUET, Dhaka

Smit B, Pilifosova O (2003) From adaptation to adaptive capacity and vulnerability reduction. In: Climate change, adaptive capacity and development. World Scientific, Singapore, pp 9-28

Statistics BBO (2016) Statistical yearbook of Bangladesh 2014, vol 2016. BBS, Dhaka, p 18

Thompson PM, Penning-Rowsell E (1994) Socio-economic impacts of floods and flood protection: a Bangladesh case study. In: Disasters development and environment. Wiley, Chichester, pp 81-97

Zaman M (1989) The social and political context of adjustment to riverbank erosion hazard and population resettlement in Bangladesh. Hum Organ 48(3):196

Zaman M (1993) Rivers of life: living with floods in Bangladesh. Asian Surv 33(10): 985-996

Zaman MQ-U (1996) Development and displacement in Bangladesh: toward a resettlement policy. Asian Surv 36(7):691-703

\section{Publisher's Note}

Springer Nature remains neutral with regard to jurisdictional claims in published maps and institutional affiliations.

\section{Submit your manuscript to a SpringerOpen ${ }^{\circ}$ journal and benefit from:}

- Convenient online submission

- Rigorous peer review

- Open access: articles freely available online

High visibility within the field

- Retaining the copyright to your article

Submit your next manuscript at $>$ springeropen.com 